\title{
Surface integrity analysis of WEDMed specimen of Inconel 825 superalloy
}

\author{
Pawan Kumar ${ }^{a^{*}}$, Meenu Gupta a and Vineet Kumar
}

${ }^{a}$ Department of Mechanical Engineering, National Institute of Technology, Kurukshetra, India ${ }^{b}$ Department of Mechanical Engineering, UIET, Maharishi Dayanand University, Rohtak, India

\section{CH R O N I C L E}

\begin{tabular}{l}
\hline Article history: \\
Received: May 1, 2018 \\
Received in revised format: June \\
16,2018 \\
Accepted: July 26, 2018 \\
Available online: \\
July 26, 2018 \\
\hline Keywords: \\
WEDM \\
Inconel 825 \\
Surface crack density \\
Microstructure \\
Recast layer
\end{tabular}

\section{Introduction}

Superalloys are extensively used in aerospace industries, petrochemical industries, food processing industries and pollution control equipments due to their good mechanical strength at high temperature (Thellaputta et al., 2017). Among Nickel based superalloys, Inconel series possesses high temperature corrosion resistance, oxidation resistance and creep resistance properties which are important for aerospace industry for manufacturing of turbine disks, blades, combustors and casing (Aggarwal et al., 2015). Inconel 825 possesses superior mechanical properties, provides resistance to chloride pitting as well as resistance to a variety of oxidizing atmospheres than other Inconel alloys (Rajyalakshmi and Venkata Ramaiah, 2013; Kumar et al., 2018).

\footnotetext{
* Corresponding author. Tel.: +91-9996260406

E-mail address: nain.pawan2@gmail.com (P. Kumar)

(C) 2018 by the authors; licensee Growing Science, Canad doi: $10.5267 /$ j.ijdns.2018.8.001
} 
One of the major problems faced while machining of Inconel 825 with conventional method is generation of high temperature between tool and workpiece that causes formation of chips and built up edges resulting in decreased surface integrity. This is due to presence of high abrasive particles in its microstructure and its low thermal conductivity (Singh et al., 2015). To provide the effective solution, WEDM a nontraditional method has been used for machining of superalloys to meet the requirement of high degree of precision and accuracy. WEDM has been used for machining of a vast range of electrically conductive materials such as steels (Lodhi et al., 2014), titanium alloys (Nourbakhsh et al., 2013) and superalloys (Caydas et al., 2016), disregarding of their strength and hardness. As the tool never comes into contact with the work piece, less stress is created in work material. Fragile and thin sections can easily be machined without deformation (Ghodsiyeh et al., 2013).

Since WEDM process occurs at very high temperature $\left(8000-12000^{\circ} \mathrm{C}\right)$, it is having significant impact on the surface integrity of the work piece. Surface parameters including surface morphology, surface roughness, residual stress, microstructure, and micro-hardness are crucial in determining the final performance of the machined specimen. The formation of heat affected zone, microcracks, recast layer, porosity etc. remains a big problem in surface structure of machined specimen during WEDM process (Shen et al., 2017). Therefore, analysis of surface integrity is required to determine the final performance of the machined product.

Various studies have been reported on surface integrity studies of WEDM machined steels (Kanlayasiri et al., 2007; Chuanliang et al., 2014; Khan et al., 2014) but there are very few reports on the surface integrity analysis of nickel-based superalloys (Chen et al., 2016; Garg et al., 2017). Li et al. (2013) analyzed the surface integrity characteristics in machining of Inconel 718 at different discharge energy. EDMed surface topography showed dominant coral reef microstructures at high discharge energy, while random micro voids were dominant at low discharge energy. They observed that average surface roughness is significantly reduced at low discharge energy. The thin white layers by trim cut at low discharge energy become more continuous, uniform, and are free of micro voids (Li et al., 2013). In another study, Aspinwall et al. (2008) reported on machining of Inconel 718 with WEDM, workpiece surface damage was extremely low at high frequency/ short pulses duration. Microstructural profile data like average recast thickness were observed to be less than $11 \mu \mathrm{m}$ which mean there is no surface damage (Aspinwall et al., 2008).

In micro-structural analysis, crater diameter and crater depth on tool surface and workpiece surface are very important parameters to study. Tosun et al. (2003) found that crater diameter and crater depth increased with increase in open circuit voltage, pulse duration and wire speed whereas dielectric flushing pressure was less effective for determining the crater diameter and depth. In another report, micro-structural characterization was carried out for welded joint of two dissimilar material austenitic AISI 304 stainless steel and Inconel 600 using Nd:YAG laser welding. They observed that during solidification temperature gradient, solidification speed and chemical composition influences the morphology of welded zone (Neves et al., 2010).

Talla and Gangopadhyay (2016) showed that during machining of IN 625, addition of silicon powder had significantly improved surface integrity resulting in 14\% more hardness than graphite as compared to pure dielectric. Lowest surface roughness and least residual stress were obtained using silicon powder. Thakur et al. (2014) investigated the effect of cutting speed and chemical vapour deposition (CVD) multilayer coating on machined surface integrity of Inconel 825 during dry turning. It was observed that increase in cutting speed increased white layer thickness after machining with both uncoated and coated tools. CVD coated cemented carbide insert resulted in decrease in white layer thickness particularly in the lower range of cutting velocity when compared with that obtained by its uncoated counterpart. Thus, WEDM machining parameters have significant influence on the surface integrity aspects of machined surface. This study aims to address the effect of different process parameters of WEDM on surface integrity of Inconel 825 machined under conditions optimized through response surface methodology. 


\section{Experimental procedures}

Inconel $825(150 \mathrm{~mm} \times 150 \mathrm{~mm} \times 10 \mathrm{~mm})$ was used as work material for the present study. Table 1 shows the chemical and physical properties of work material. Sprint cut computer numerical controlled (CNC) Wire Electrical Discharge Machining (WEDM) tool is used for machining.

Table 1

Chemical and physical properties of Inconel 825

\begin{tabular}{|c|c|}
\hline \multicolumn{2}{|c|}{ Chemical Composition } \\
\hline Element & Content (\%) \\
\hline $\mathrm{Ni}$ & $38-46$ \\
\hline $\mathrm{Fe}$ & 22 \\
\hline $\mathrm{Cr}$ & $19.5-23.5$ \\
\hline Mo & $2.5-3.5$ \\
\hline $\mathrm{Cu}$ & $1.5-3.0$ \\
\hline $\mathrm{Ti}$ & $0.6-1.2$ \\
\hline $\mathrm{C}$ & $0.05 \max$ \\
\hline $\mathrm{P}$ & $0.02 \max$ \\
\hline $\mathrm{S}$ & $0.03 \max$ \\
\hline $\mathrm{Mg}$ & $1.0 \max$ \\
\hline \multicolumn{2}{|c|}{ Physical properties } \\
\hline Density & $8.14 \mathrm{~g} / \mathrm{cm}^{3}$ \\
\hline Melting Point & $1400^{\circ} \mathrm{C}$ \\
\hline Coefficient of expansion & $14.0 \mathrm{~m} / \mathrm{m} /{ }^{\circ} \mathrm{C}\left(20-100^{\circ} \mathrm{C}\right)$ \\
\hline Modulus of rigidity & $75.9 \mathrm{~N} / \mathrm{mm}^{2}$ \\
\hline Modulus of elasticity & $196 \mathrm{kN} / \mathrm{mm}^{2}$ \\
\hline
\end{tabular}

The workpiece was mounted with the help of a fixture on the machine table. The electrode material used was a single-strand plain brass wire of diameter $0.25 \mathrm{~mm}$. Wire was fed through the workpiece continuously by a micro processor. The upper head supplied the fresh wire under tension through the workpiece and lower head received the used wire after machining (Fig. 1). A suitable gap of $0.025-0.5 \mathrm{~mm}$ was maintained between wire and the workpiece. High frequency pulse of AC or DC was discharged from wire to workpiece with a very small spark gap through an insulated dielectric field. The material gets removed from wire and workpiece by the thermoelectric erosion process. When an electric field is applied, the gap voltage reached the breakdown voltage and high power spark was produced which increase the temperature to about $8000-10000^{\circ} \mathrm{C}$ in between the smallest gap where plasma zone occurs. During machining, the debris produced by the erosion process was flushed by the dielectric fluid continuously fed through upper and lower nozzles to the sparking area along the wire. 


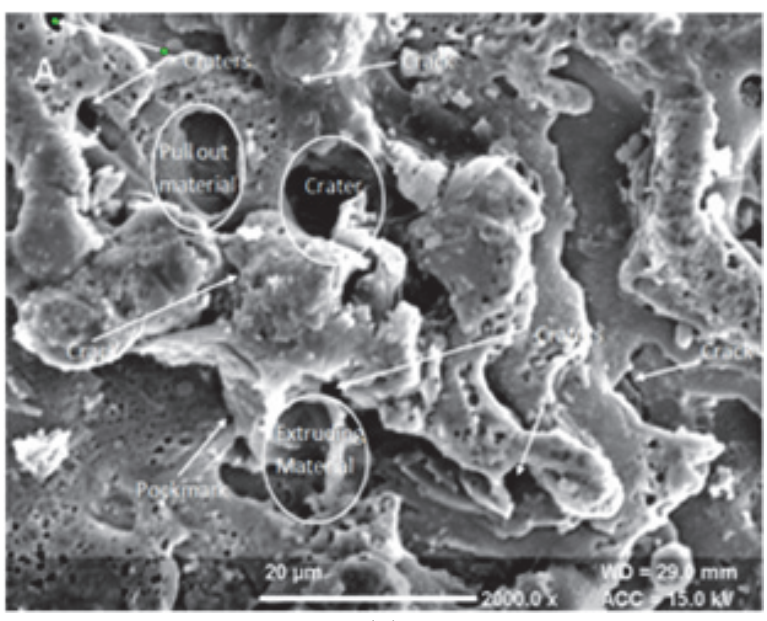

(a)

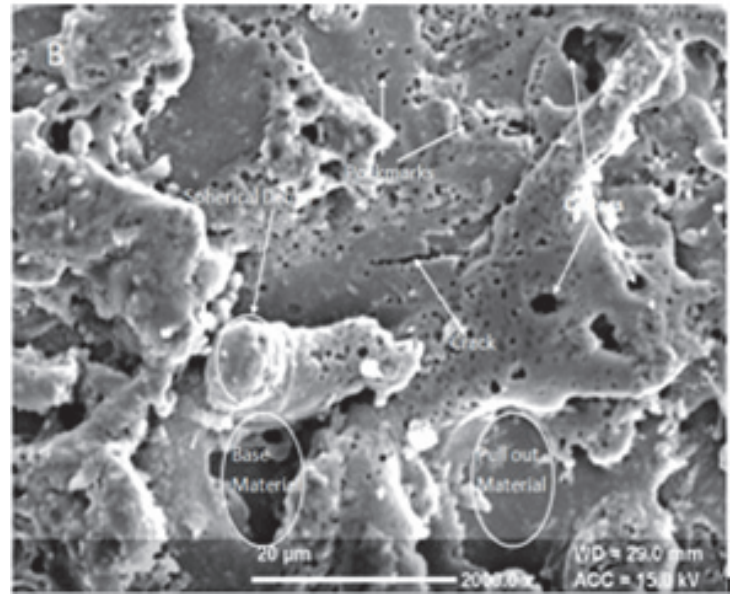

(b)

Fig. 1. Wire characteristics

\subsection{Experimental design}

Surface integrity analysis was carried out on WEDM machined samples of Inconel 825 . The sample was machined under optimized conditions obtained through RSM. Six parameters i.e. pulse on time $\left(\mathrm{T}_{\mathrm{on}}\right)$, pulse off time $\left(\mathrm{T}_{\text {off }}\right)$, peak current (IP), gap voltage $(\mathrm{SV})$, wire tension (WT) and wire feed (WF) were chosen as input parameters. The actual and coded values of the input variables are shown in Table 2. Some factors which are expected to have an effect on performance measure viz. product size and shape (rectangular), temperature of the dielectric $\left(28^{\circ} \mathrm{C}\right)$, conductivity of the dielectric $(20 \mathrm{mho})$, work piece thickness $(10 \mathrm{~mm})$, wire type $(0.25 \mathrm{~mm}$ diameter brass $)$ and angle of cut (vertical) are kept constant. The machining performance was measured in terms of material removal rate (MRR), surface roughness (SR) and wire wear ratio (WWR).

Table 2

Experimental factors and their levels for wire electrical discharge machining process

\begin{tabular}{|c|c|c|c|c|c|c|c|c|}
\hline S. No. & Symbol & Parameter & Units & $\begin{array}{c}\text { Level } 1 \\
(-2)\end{array}$ & $\begin{array}{c}\text { Level } 2 \\
(-1)\end{array}$ & $\begin{array}{c}\text { Level } 3 \\
0\end{array}$ & $\begin{array}{c}\text { Level } 4 \\
-1\end{array}$ & $\begin{array}{c}\text { Level } 5 \\
-2\end{array}$ \\
\hline 1 & A & $\begin{array}{l}\text { Pulse on time } \\
\qquad\left(T_{\text {on }}\right)\end{array}$ & $\mu \mathrm{s}$ & 107 & 109 & 111 & 113 & 115 \\
\hline 2 & $\mathrm{~B}$ & $\begin{array}{l}\text { Pulse off time } \\
\qquad\left(\mathrm{T}_{\mathrm{off}}\right)\end{array}$ & $\mu \mathrm{s}$ & 32 & 35 & 38 & 41 & 44 \\
\hline 3 & $\mathrm{C}$ & $\begin{array}{c}\text { Gap Voltage } \\
\text { (CS) }\end{array}$ & $\mathrm{V}$ & 42 & 46 & 50 & 54 & 58 \\
\hline 4 & $\mathrm{D}$ & $\begin{array}{l}\text { Peak Current } \\
\text { (IP) }\end{array}$ & A & 110 & 120 & 130 & 140 & 150 \\
\hline 5 & $\mathrm{E}$ & $\begin{array}{c}\text { Wire Tension } \\
\text { (WT }\end{array}$ & kg-f & 8 & 9 & 10 & 11 & 12 \\
\hline 6 & $\mathrm{~F}$ & $\begin{array}{l}\text { Wire feed rate } \\
\text { (WF) }\end{array}$ & $\mathrm{m} / \mathrm{min}$ & 4 & 5 & 6 & 7 & 8 \\
\hline
\end{tabular}

Material was cut under optimized conditions i.e. 111 machine unit $\mathrm{T}_{\text {on }}, 35$ machine unit $\mathrm{T}_{\text {off, }}$ 46V SV, 140A IP, 9 machine unit WT and $6 \mathrm{~m} / \mathrm{min} \mathrm{WF}$ and the resulting values of MRR, SR and WWR were $32.015 \mathrm{~mm}^{2} / \mathrm{min}, 2.5283 \mu \mathrm{m}$ and 0.000305 respectively (Table 3 ). 
Table 3

Output responses at optimum combination of machining parameters

\begin{tabular}{|c|c|c|c|c|c|c|c|c|c|c|c|}
\hline \multirow{2}{*}{$\begin{array}{c}\text { Type of } \\
\text { optimization }\end{array}$} & \multirow[t]{2}{*}{ Objective } & \multicolumn{6}{|c|}{ Optimization parameters } & \multirow{2}{*}{$\begin{array}{l}\text { Response } \\
\text { (Predicted) }\end{array}$} & \multirow{2}{*}{$\begin{array}{l}\text { Response } \\
\text { (Experi- } \\
\text { mental) }\end{array}$} & \multirow[t]{2}{*}{ Desirability } & \multirow[t]{2}{*}{$\%$ error } \\
\hline & & Ton & Toff & SV & IP & WT & WF & & & & \\
\hline Multi response & $\begin{array}{l}\text { Maximize } \\
\text { MRR \& Mini- } \\
\text { mize SR, } \\
\text { WWR }\end{array}$ & 111 & 35 & 46 & 140 & 9 & 6 & $\begin{array}{l}31.098, \\
2.4306, \\
0.000299\end{array}$ & $\begin{array}{l}32.015 \\
2.5283 \\
0.000305\end{array}$ & 0.807 & $\begin{array}{l}2.86 \\
3.87 \\
1.96\end{array}$ \\
\hline
\end{tabular}

\subsection{Scanning electron microscopic study of the WEDM machined Inconel 825}

Inconel 825 was cut under optimal conditions with WEDM and all measurement related to surface micrograph were performed on JEOL scanning electron Microscope (Model 6100, JEOL, USA); a profile measuring microscope that determine the surface microstructures, formation of recast layer and heataffected zone of the work material. Etching process of machined sample was carried out with krolls reagent $(2 \%(\mathrm{v} / \mathrm{v})$ hydrofluoric acid, $10 \%(\mathrm{v} / \mathrm{v})$ nitric acid). Then, the samples were cleaned using acetone $\left(\mathrm{CH}_{3}\right)_{2} \mathrm{CO}$ for scanning electron micrograph.

Crack length and area of the micrograph was observed by using Axio-vision software for finding surface crack density and recast layer thickness calculated by using the following formulae:

$$
S C D_{i}=L C_{i} / A_{i}
$$

where,

$\mathrm{SCD}_{\mathrm{i}}=$ Surface crack density,

$\mathrm{LC}_{\mathrm{i}}=$ Length of the crack $(\mu \mathrm{m})$,

$\mathrm{A}_{\mathrm{i}}=$ Area of the micrograph $\left(\mu \mathrm{m}^{2}\right)$

$$
R C L_{t}=R C L_{A i} / R C_{L i}
$$

where,

$\mathrm{RCL}_{\mathrm{t}}=$ Recast layer thickness $(\mu \mathrm{m})$,

$\mathrm{RCL}_{\mathrm{Ai}}=$ Recast layer area $\left(\mu \mathrm{m}^{2}\right)$,

$\mathrm{RC}_{\mathrm{Li}}=$ Recast layer length $(\mu \mathrm{m})$

2.3 Elemental and phase analysis of machined Inconel 825

The very high temperatures used in WEDM process instantly melt and vaporize surface work material during the discharge process. Complex chemical reactions between the work material, wire material, and the dielectric are the basic characteristics of an EDM process. Energy Dispersive spectrograph (EDS) analysis was used to measure the element composition of machined surface. X-ray diffraction was used to study the phases of WEDM machined Inconel 825

\section{Results and discussion}

Surface topography study including micro-cracks, craters, debris, pockmarks, heat affected zone, recast layer and transfer of the metal particles from wire electrode to work surface, are important parameters for analyzing the surface integrity of WEDM machined materials (Shen et al., 2017). In the present study, Inconel 825 machined with WEDM under conditions optimized through RSM was used for studying the effect of machining parameters on machined surface. Scanning electron micrograph, EDS and XRD analysis were performed for the work material to analyze the surface of machined samples. 


\subsection{Surface structure of machined sample}

SEM Micrograph of the WEDMed surface of Inconel 825 is shown in Fig 1. It can be observed from the micrograph that the machined surface was composed of pulled out material that are not flushed from the surface by liquid pressure (Fig. 1a-b). The material is removed in the form of spherical chips during WEDM process which in turn produce craters and pockmarks on the surface (Holmberg et al., 2017). It is clearly demonstrated by the micrograph that the surface topography of WEDmed sample is a function of discharge energy which inturn is a funtion of pulse on time and pulse off time. At high vaule of pulseon time and low value of pulse off time, high heat transfers toward the workpiece surface which causes melting and evaporation of more work material from the surface resulting in deep craters and pockmarks on the surface (Fig. 1a). When the pulse off time increases and pulse on time decreases, a relatively low craters and pockmarks were observed (Fig. 1b). This can be because of the reason that due to rapid heating and quenching, the local temperature increases more than the melting point of the material resulting in the formation of cracks with the development of high thermal stress exceeding the plastic deformation (Kumar et al., 2016). In this study the size and density of cracks were measured in terms of surface crack density at low and high discharge energy by using equation 1 . Axio vision software was used to calculate the total length of the cracks of the given micrograph and total area of the micrograph

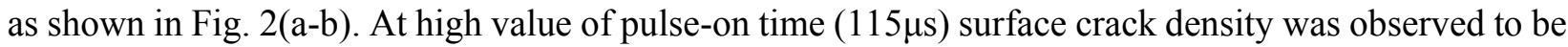
$0.0138 \mu \mathrm{m} / \mu \mathrm{m}^{2}$ (Fig. 2a), while at low value $(107 \mu \mathrm{s})$, the SCD was observed to be $0.0016 \mu \mathrm{m} / \mu^{2}{ }^{2}$ (Fig. 2b).

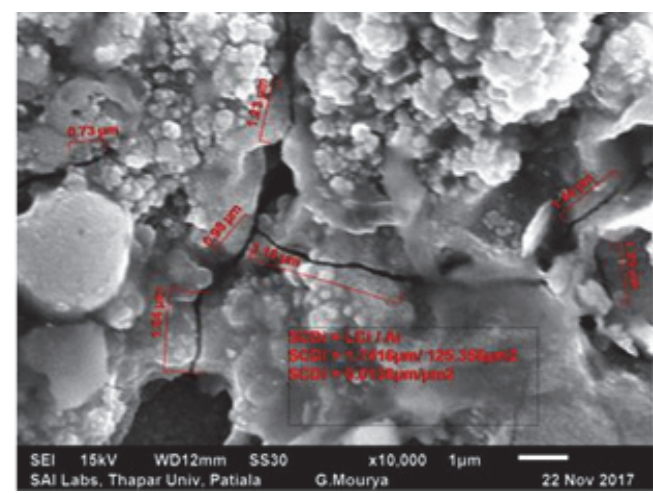

(a)

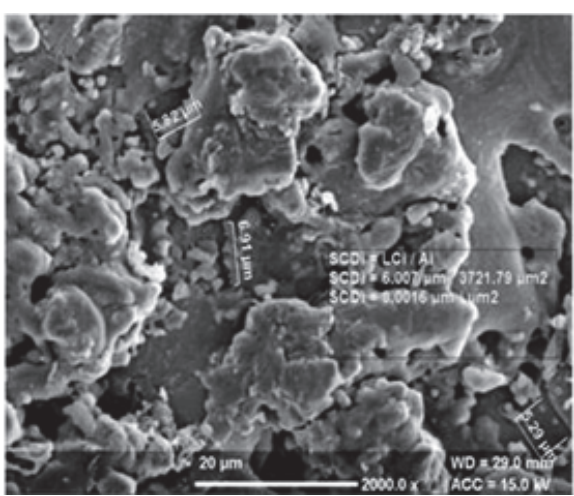

(b)

Fig. 2. Total length of the cracks of the given micrograph and total area of the micrograph

Microsturcture changes was also observed for the tool electrode due to thermal stresses developed at interaface of tool and workpiece (Fig. 3a-b).

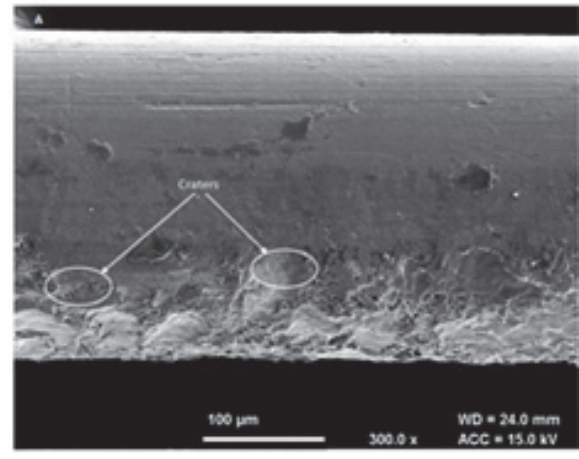

(a)

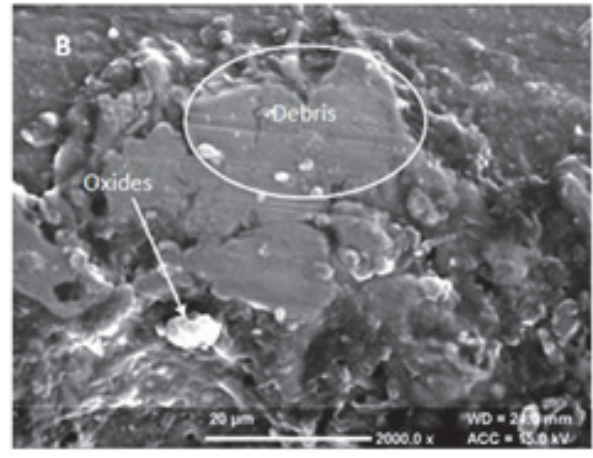

(b)

Fig. 3. Microsturcture changes was also observed for the tool electrode due to thermal stresses developed at interaface of tool and workpiece 
Different craters and residuals of debris were found on the surface of wire electrode. The developed stresses in wire was more than the wire strength due to increase of peak current (140 A), wire tension $(9$ $\mathrm{kg}-\mathrm{f}$ ) and poor flushing pressure which may result in wire rupture and wire beakeage.

\subsection{Recast layer thickness of machined sample}

Through the SEM micrograph, it was observed that three region were developed during cutting operation (Fig. 4a). At very top an appearance was observed at the cross section of WEDMed work surface known as recast layer. Recast layer is the layer formed by re-solidification of the melted material on the work surface which is not ejected by the flushing pressure or dielectric fluid. Below recast layer there is heat affected zone where no melting material is present on the work surface but the micro-structure changes from the base material due to intense heat transfer. At the bottom, there is base material.

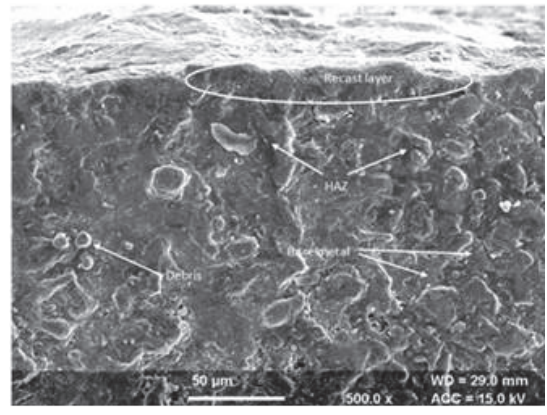

(a)

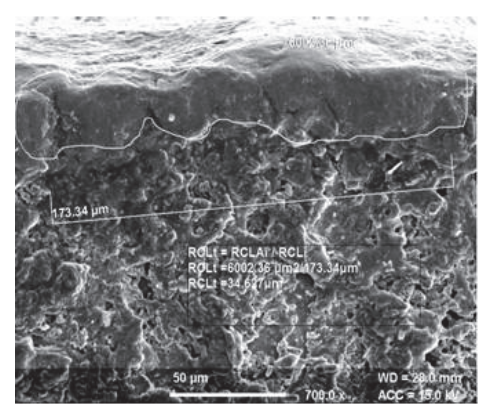

(b)

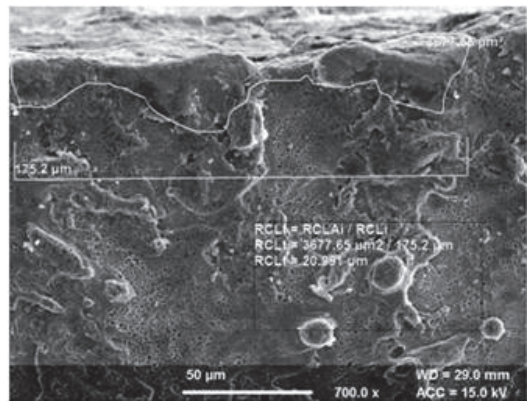

(c)

Fig. 4. Three regions developed during cutting operation

Average recast layer thickness of optimized run was calculated by using the Eq. (2) and Axio vision software was used for measurement of area and length of recast layer. As we know that intense heat was influenced by pulse-on time and pulse off time (Kolli \& Kumar, 2015), so increase in pulse-on time increases the amount of melted material from the work surface resulting in increase in average recast layer thickness up to $34.62 \mu \mathrm{m}$ at high value of pulse-on time $115 \mu \mathrm{s}$ (Fig. 4b). At low value of pulse on time and high value of pulse off time, the thickness of recast layer was reduced to $20.99 \mu \mathrm{m}$ (Fig. 4c). Thus, the formation of recast layer depends upon the process parameters and workpiece properties like thermal conductivity. Due to rapid melting and solidification process, the thickness of recast layer altered.

\subsection{Elemental and phase analysis of machined sample}

From the EDX analysis of work specimen, it was observed that some metal particles are present on the work surface other than base material because during WEDM process some of the debris cannot be flushed from the sparking gap so that rest part of debris get deposited on the surface as compounded form (Fig. 5). EDX analysis showed that significant amount of elements migrated from wire electrode to workpiece. Fe (Ferrous), Cr (Chromium), Cu (Copper), Ni (Nickel) was observed at highest peak in the spectrum of EDX which shows that an appreciable amount of these elements are migrated to the surface of the workpiece. Migration of the elements depends upon the value of pulse on time and gap voltage. At high value of pulse-on time and gap voltage, spark energy increases which causes more melting and evaporation of material (Khosrozadeh \& Shabgard, 2017). Some residual of the C (Carbon), Cu (Copper) and $\mathrm{O}$ (Oxygen) elements were also observed on the machined sample because of decomposition of dielectric, re-solidification of the wire electrode and mixing of the debris at elevated temperature. 


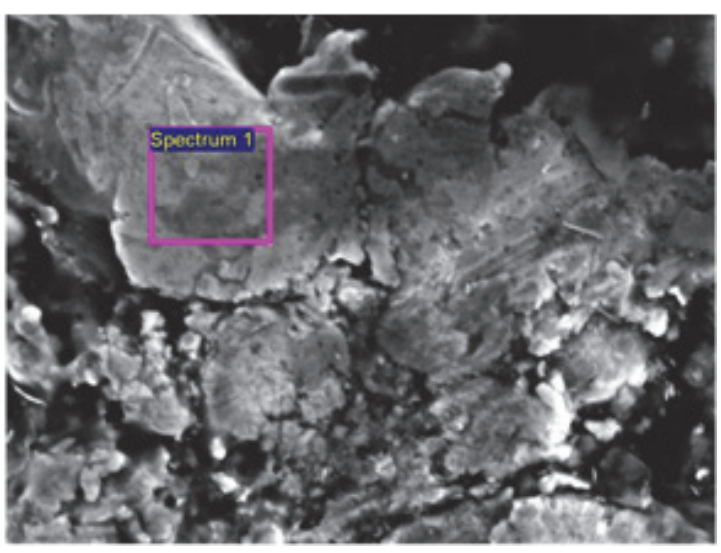

(a)

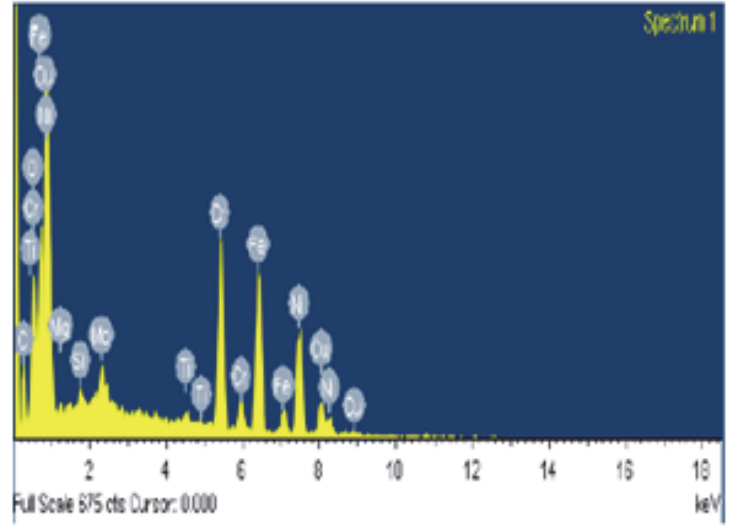

(b)

Fig. 5. EDX analysis of work specimen

The debris that gets deposited in compounded form on the work surface was examined by X-ray diffraction analysis. Different compounds were formed due to migration of workpiece elements, tool electrode elements and decomposition of deionized water. Different phases were analyzed by transfer of the tool and dielectric elements on the work surface by using X' Pert High score plus (Fig. 6). It was observed from the figure 6 that copper dioxides $\left(\mathrm{CuO}_{2} 44 \%\right)$, Chromium Molybdenum Nickel dioxides $\left(\mathrm{Cr}_{9} \mathrm{Mo}_{21}\right.$ $\mathrm{Ni}_{20} \mathrm{O}_{2} 12 \%$ ), Iron Nickel ( $\mathrm{Fe} \mathrm{Ni}_{3} 44 \%$ ) were found as compounded form on the surface of the specimen (Table 4).

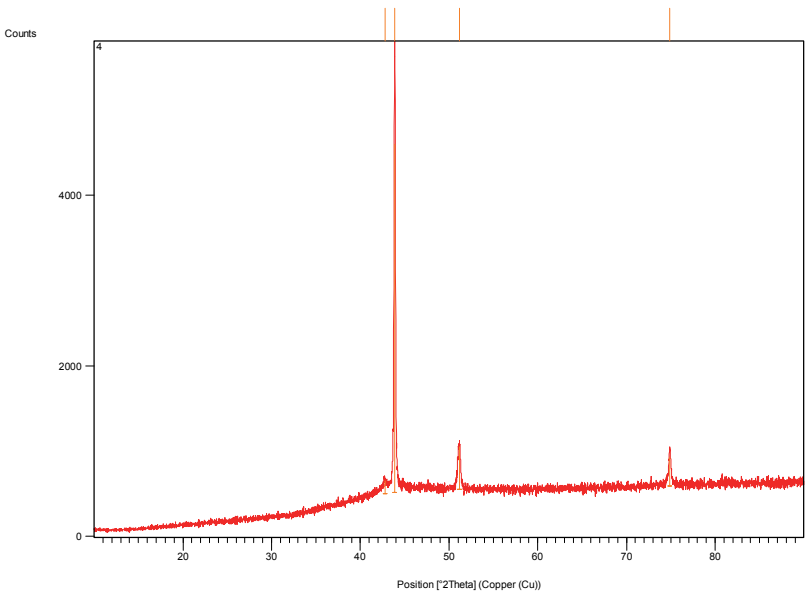

Fig. 6. The changes of dielectric elements on the work surface

\section{Table 4}

XRD phase pattern analysis of identified phases

\begin{tabular}{cccc}
\hline Ref. Code & Compound Name & Chemical Formula & Semi Quant [\%] \\
\hline $03-065-9743$ & Copper dioxides & $\mathrm{Cu} \mathrm{O}_{2}$ & 44 \\
$03-065-7733$ & Chromium Molybdenum & $\mathrm{Cr}_{9} \mathrm{Mo}_{21} \mathrm{Ni}_{20} \mathrm{O}_{2}$ & 12 \\
$01-071-8323$ & Iron Nickel dioxides & $\mathrm{Fe} \mathrm{Ni}_{3} \mathrm{O}_{2}$ & 44 \\
\hline
\end{tabular}

\section{Conclusion}

The present study deals with the microstructure analysis of WEDMed machined sample (Inconel 825) at high and low value of pulse on time and pulse off time. Surface topography of machined sample is highly dependent on discharge energy. At low value of pulse on time and high value of pulse off time, less 
numbers of craters, cracks and pockmarks were observed. The surface crack density and recast layer thickness was also observed to be minimum. With increase in pulse on time and decrease in pulse off time, the discharge energy increases which inturn increased the surface crack density and recast layer thickness. Thus, discharge energy is the most influencing parameters for maintaining the surface integrity of WEDmed samples of Inconel 825.

\section{References}

Aggarwal, V., Singh, S., \& Garg, R.K. (2015) Parametric modeling and optimization for wire electrical discharge machining of Inconel 718 using response surface methodology. International Journal of Advanced Manufacturing Technology, 79, 31-47.

Aspinwall, D.K., Soo, S.L., Berrisford, A.E., \& Walder, G. (2008). Workpiece surface roughness and integrity after WEDM of Ti 6Al 4V and Inconel 718 using minimum damage generator technology. CIRP Annals, 57(1), 187-190.

Çaydas, U., \& Ay, M. (2016). WEDM cutting of Inconel 718 nickel-based superalloy: effects of cutting parameters on the cutting quality. Materials and Technology, 1, 117-125.

Chen, Z., Moverare, J., Peng, R.L., \& Johansson, S. (2016). Surface Integrity and Fatigue Performance of Inconel 718 in Wire Electrical Discharge Machining. Procedia CIRP, 45, 307-310.

Chuanliang, C., Xianglin, Z., Xiang, Z, \& Chunfa, D. (2014). Surface Integrity of Tool Steels Multi-cut by Wire Electrical Discharge Machining. Procedia Engineering, 81, 1945-1951.

Garg, M.P., Kumar, A., \& Sahu, C.K. (2017). Mathematical modeling and analysis of WEDM machining parameters of nickel-based super alloy using response surface methodology. Sadhana, 42(6), 9811005.

Ghodsiyeh, D., Golshan, A., \& Shirvanehdeh, J.A. (2013). Review on current research trends in wire electrical discharge machining (WEDM). Indian Journal of Science and Technology, 6, 154-166.

Holmberg, J., Wretland, A., Berglund, J., \& Beno, T. (2018). Surface integrity after post processing of EDM processed Inconel 718 shaft. The International Journal of Advanced Manufacturing Technology, 95(5-8), 2325-2337.

Kanlayasiri, K., \& Boonmung, S. (2007). Effects of wire-EDM machining variables on surface roughness of newly developed DC 53 die steel: Design of experiments and regression model. Journal of Materials Processing Technology, 192-193, 459-464.

Khan, N. Z., Khan, Z. A., Siddiquee, A.N., \& Chanda A.K. (2014). Investigations on the effect of wire EDM process parameters on surface integrity of HSLA: a multi-performance characteristics optimization. Production and Manufacturing Reserarch, 2(1), 501-518.

Kolli, M., \& Kumar, A. (2015) Effect of dielectric fluid with surfactant and graphite powder on Electrical Discharge Machining of titanium alloy using Taguchi method. International Journal of Engineering Science and Technology, 18, 524-535.

Kumar, A., Kumar, V., \& Kumar, J. (2016). Surface crack density and recast layer thickness analysis in WEDM process through response surface methodology. Machining Science and Technology, 20, 201230.

Kumar, P., Meenu, \& Kumar, V. (2018). Optimization of process parameters for WEDM of Inconel 825 using grey relational analysis. Decision Science Letters, 7(4), 405-416.

Li, L., Guo, Y.B., Wei, X.T., \& Li, W. (2013). Surface integrity characteristics in wire-EDM of inconel 718 at different discharge energy. Procedia CIRP, 6, 220-225.

Lodhi, B. K., \& Agarwal, S. (2014). Optimization of Machining Parameters in WEDM of AISI D3 Steel Using Taguchi Technique. Procedia CIRP, 14, 194 - 199.

Neves, M.D., Lotto, A., Berretta, J.R., de Rossi, W., \& Junior, N.D. (2010). Microstructure development in Nd:YAG laser welding of AISI 304 and Inconel 600. Welding International, 24, 739-748.

Nourbakhsh, F., Rajurkar, K.P., Malshe, A.P., \& Cao. J. (2013). Wire Electro-Discharge Machining of Titanium Alloy. Procedia CIRP, 5, 13-18. 
Rajyalakshmi, G., \& Venkata Ramaiah, P. (2013). Multiple process parameter optimization of wire electrical discharge machining on Inconel 825 using Taguchi grey relational analysis. International Journal of Advanced Manufacturing Technology, 69, 1249-1262.

Shen, Y., Liu, Y., Dong, H., Zhang, K., Lv, L., Zhang, X., Wu, X., Zheng, C., \& Ji, R. (2017). Surface integrity of Inconel 718 in high-speed electrical discharge machining milling using air dielectric. International Journal of Advanced Manufacturing Technology, 90, 691-698.

Singh, A., Anandita, S., \& Gangopadhyay, S. (2015). Microstructural analysis and multi response optimization during ECM of Inconel 825 using hybrid approach. Materials and Manufacturing Processes, 30, 842-851.

Talla, G., Gangopadhyay, S., \& Biswas, C. K. (2018). Effect of impregnated powder materials on surface integrity aspects of Inconel 625 during electrical discharge machining. Proceedings of the Institution of Mechanical Engineers, Part B: Journal of Engineering Manufacture, 232(7), 1259-1272.

Thakur, A., Mohanty, A., Gangopadhyay, S., \& Maity, K.P. (2014). Tool wear and chip characteristics during dry turning of Inconel 825. Procedia Material Science, 5, 2169-2177.

Thellaputta, G. R., Pulcharu, S. C., \& Rao, C.S.P. (2017). Machinability of Nickel Based Superalloys: A Review. Materials Today: Proceedings, 4(2), 3712-3721.

Tosun, N., \& Pihtili, H. (2003). The effect of cutting parameters on wire crater sizes in wire EDM. International Journal of Advanced Manufacturing Technology, 21, 857-865.

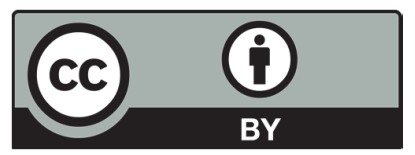

(C) 2018 by the authors; licensee Growing Science, Canada. This is an open access article distributed under the terms and conditions of the Creative Commons Attribution (CCBY) license (http://creativecommons.org/licenses/by/4.0/). 